\title{
PRODUCTS LIABILITY AND EVIDENCE OF SUBSEQUENT REPAIRS
}

The theories of strict liability in tort ${ }^{1}$ and implied warranty ${ }^{2}$ enable a plaintiff injured by a defective product to recover damages from the product's manufacturer or distributor with whom he is not in privity ${ }^{3}$ and whose negligent conduct has not been established. ${ }^{4} \mathrm{Al}-$ though these new theories ${ }^{5}$ of liability have made recovery easier, the

1. For a statement of the theory of strict tort liability, see RESTATEMENT (SECOND) OF TORTS $\$ 402$ A (1965):

Special Liability of Seller of Product for Physical Harm to User or Consumer

(1) One who sells any product in a defective condition unreasonably dangerous to the user or consumer or to his property is subject to liability for physical harm thereby caused to the ultimate user or consumer, or to his property, if

(a) the seller is engaged in the business of selling such a product, and

(b) it is expected to and does reach the user or consumer without substantial change in the condition in which it is sold.

(2) The rule stated in Subsection (1) applies although

(a) the seller has exercised all possible care in the preparation and sale of his product, and

(b) the user or consumer has not bought the product from or entered into any contractual relation with the seller.

THE FOLLOWING HEREINAFTER CITATIONS WILL BE USED IN THIS NOTE:

RESTATEMENT (SECOND) OF TORTS (1965) [hereinafter cited as RESTATEMENT];

Carmichael, Strict Liability in Tort-An Explosion in Products Liability Law, 20 DrAKE

L. REv. 528 (1971) [hereinafter cited as Carmichael].

2. Implied warranty is codified in the UNIFORM COMMERCIAL CODE \& 2-3I4(1): Implied Warranty: Merchantability: Usage of Trade. . . . [A] warranty that the goods shall be merchantable is implied in a contract for their sale if the seller is a merchant with respect to goods of that kind ....

3. See Henningsen v. Bloomfield Motors, Inc., 32 N.J. 358, 413, 161 A.2d 69, 100 (1960): "[L]ack of privity does not stand in the way of prosecution of the injury suit against the defendant...."

See also UNiform Commercial Code $\S$ 2-318:

Third Party Beneficiaries of Warranties Express or Implied. A seller's warranty whether express or implied extends to any natural person who is in the family or household of his buyer or who is a guest in his home if it is reasonable to expect that such person may use, consume or be affected by the goods and who is injured in person by breach of the warranty. A seller may not exclude or limit the operation of this section.

4. "A manufacturer is strictly liable in tort when an article he places on the market, knowing that it is to be used without inspection for defects, proves to have a defect that causes injury to a human being." Greenman v. Yuba Power Prods., 59 Cal. 2d 57, 62, 377 P.2d 897, 900, 27 Cal. Rptr. 697, 700 (1962). See also Restatement § 402A(2).

5. The new theories-strict liability in tort and implied warranty without privity of contract-are the result of a "revolution" during the last decade in products liability law. There had been a gradual evolution for more than a century. In 1842 one court said: "[I]t is, no doubt, a hardship upon the plaintiff to be without a remedy, but by that consideration we ought not be influenced." Winterbottom v. Wright, 10 M. \& W. 109, 116, 152 Eng. Rep. 402, 405 (Ex. 
products liability plaintiff must still prove, inter alia, ${ }^{6}$ the defectiveness of the injury-causing product ${ }^{7}$ and the defendant's control over the product when it was in such defective condition. ${ }^{8}$ These elements of the plaintiff's case must be established by more

1842) (plaintiff-mail coach driver for Postmaster General could not recover from supplier of mail coach for injury caused by latent defect in coach). But in the early twentieth century a strict liability in tort or implied warranty developed in unwholesome food cases, beginning with Mazetti v. Armour \& Co., 75 Wash. 622, 135 P. 633 (1913) (cooked tongue), extended to "inherently" or "imminently" dangerous products, MacPherson v. Buick Motor Co., 217 N.Y. 382, 111 N.E. 1050 (1916) (automobile), and to articles for intimate bodily use, Graham v. Bottenfield's, Inc., 176 Kan. 68, 269 P.2d 413 (1954) (hair preparation). The revolution which extended the new theories of products liability law to all products began with Henningsen $v$. Bloomfield Motors, Inc., 32 N.J. 358, 161 A.2d 69 (I960) (automobile), and Greenman v. Yuba Power Prods., 59 Cal. 2d 57, 377 P.2d 897, 27 Cal. Rptr. 697 (1962) (combination power tool). For the development of the recent revolution in products liability law, see Carmichael; Prosser, The Fall of the Citadel (Strict Liability to the Consumer), 50 MiNN. L. Rev. 791 (1966); Traynor, The Ways and Meanings of Defective Products and Strict Liability, 32 TENN. L. REv. 363 (1965); Waddams, Strict Liabilities, Warranties, and the Sale of Goods, 19 U. TORONTO L. REv. 157 (1969).

6. In addition to the elements of defectiveness and control, the plaintiff must establish that the defendant sold the defective product, that the defect was the proximate cause of the injuries of which the plaintiff complains, and that the defendant was engaged in the business of selling such products. RESTATEMENT $\S 402 \mathrm{~A}(1)$.

7. A defect in a product may be of two types: (1) an unintentional defect in the condition of the product resulting from an error, whether negligently caused or not, in the manufacturing of a product such that the defect may occur in only one unit of the product; and (2) a product which is manufactured as designed, but which nevertheless causes an injury because it is defective in its design. L. Frumer \& M. FriedMan, Products LiabilitY § 16A[4][e] (1970).

In a definitional sense, a defect in a product is a significant risk of physical harm to a definable class of consumers or users which the normal member thereof would not anticipate or guard against. See generally Dickerson, How Good Does a Product Have To Be?, 42 IND. L.J. 301 (1967).

There are two legal tests for defects in a product: "unmerchantable," defined as a product unfit "for the ordinary purposes for which such goods are used," UNIFORM COMMERCIAL CODE $\S 2-314(2)(c)$; and "unreasonably dangerous," which may be defined as a danger beyond that which would be contemplated by the ordinary consumer or user who has knowledge common to the community as to the product's characteristics, RESTATEMENT $\S 402 \mathrm{~A}$ and comments $g$ k. See also Emroch, Testimony and Proof in a Products Liability Case, 1966 A.B.A. Section INS., N. \& C.L. 172, 179-80.

If a product were unreasonably dangerous, seemingly it would also be unfit for the purpose for which it was ordinarily intended, and it has been held that the test for unmerchantability is equivalent to the unreasonably dangerous test for strict liability in tort. Santor v. A \& M Karagheusian, Inc., 44 N.J. 52, 66-67, 207 A.2d 305, 313 (1965). See also Dickerson, supra, at 304; Emroch, supra, at 180-81. But see Farr v. Armstrong Rubber Co., 288 Minn. 83, 93-95, 179 N.W.2d 64, 68-71 (1970), suggesting that the tests for strict liability in tort and implied warranty are different, although the court relied only on the strict liability in tort test.

For the purpose of this Note, "defect" will be used generally, encompassing any differences between implied warranty and strict liability in tort definitions.

8. See Jakubowski v. Minnesota Mining \& Mfg., 42 N.J. 177, 183-84, 199 A.2d 826, 830 (1964), where the court stated that "plaintiff [must] show that the dangerous condition which 
than mere inferences from the occurrence of injury, ${ }^{9}$ because where the product has been removed from the defendant's control for a substantial time and intervening causes may have contributed to the injury, the doctrine of res ipsa loquitur is not applicable. ${ }^{10}$ Eyewitness testimony concerning the product's malfunction must be bolstered by expert testimony identifying the defect and its origin, ${ }^{11}$ evidence negating causes of the injury other than the product's defectiveness, and circumstantial evidence tending to prove that the product was defective while under the defendant's control. Evidence of subsequent repairs and improvements is potentially persuasive of both the product's defective condition and the defendant's control. If a defendant alters his product to eliminate the injury-causing device or to guard

he contends constitutes a breach of warranty had its genesis when the instrumentality was within the control of the manufacturer." See also Greenman v. Yuba Power Prods., 59 Cal. 2d 57, 64, 377 P.2d 897, 901, 27 Cal. Rptr. 697, 701 (1962).

9. See, e.g.. Wallace v. Knapp-Monarch Co., 234 F.2d 853 (8th Cir. 1956); Jakubowski v. Minnesota Mining \& Mfg., 42 N.J. 177, 182, 199 A.2d 826, 829 (1964). But see Greco v. Bucciconi Eng'r Co., 283 F. Supp. 978 (W.D. Pa. 1967), aff d, 407 F.2d 87 (3d Cir. 1969).

10. The doctrine of res ipsa loquitur has normally been used to establish negligence, which is not an issue in strict liability in tort or implied warranty cases. See Emroch, supra note 7, at 175-76. However, where a defcet could be established, the doctrine might be invoked to show that the product was defective when it was in the manufacturer's control if the injury occurred soon after the plaintiff gained control from the manufacturer with no evidence of intervening misuse. See, e.g., Henningsen v. Bloomfield Motors, Inc., 32 N.J. 358, 412, 161 A.2d 69, $97-$ 99 (1960) (defective automobile caused injury ten days after delivery). If, however, the product has been out of the manufacturer's control for a long time, or has passed through several hands-for example, the wholesaler, distributor and retailer-the doctrine cannot be used. Wallace v. Knapp-Monarch Co., 234 F.2d 853 (8th Cir. 1956) (res ipsa loquitur held inapplicable where injury was caused by a vaporizer borrowed from a neighbor who bought it two years previously); Jakubowski v. Minnesota Mining \& Mfg., 42 N.J. 177, 199 A.2d 826 (1964) (res ipsa loquitur inapplicable where plaintiff fails to show proper care and handling of the product subsequent to purchase). See also Carmichael 546; Keeton, Products Liability-Proof of the Manufacturer's Negligence, 49 VA. L. REv. 675, 680-81 (1963).

11. Evidence from expert testimony is often crucial in establishing a defect in a product. See, e.g., Lewis v. United States Rubber Co., 414 Pa. 626, 202 A.2d 20 (1964), where plaintiff's expert testified that, because no "tell-tale" marks were on a tire, the severed cord in the tire must have been the cause, not the result, of the explosion in the tire which caused plaintiff's injury.

There are, however, limitations to the value of expert testimony. The product may be completely destroyed in the accident which caused the injury. Even if the product is still available, experts examine the injury-causing object only after the accident; if from that belated examination they can identify a defect which caused the accident, the defect still must be traced to the defendant's control, which may be diffieult if the defect could have developed through misuse after the plaintiff gained control of the product. Keeton, Products Liability-Problems Pertaining to Proof of Negligence, 19 Sw. L.J. 26, 37 (1965). Moreover, experts are expensive and, in some instances, may all be in the employ of the defendant-manufacturer or his competitors. Hazard, Science and the Product Liability Claim, 54 A.B.A.J. 981 (1968). 
against its potential dangers, such repair or improvement tends to indicate not only that the product was previously defective, but also that the defendant had the requisite control to prevent the product from being marketed with that defect.

This Note will examine the use of evidence of subsequent repairs in products liability cases. First, the status of the rule excluding such evidence in negligence cases will be reviewed; then, consideration will be directed to whether changes in this rule are warranted when evidence of subsequent repairs is used in products liability cases predicated upon the theories of strict liability in tort and implied warranty.

\section{Evidence of Subsequent Repairs in Negligence Cases}

\section{General Exclusionary Rule}

The admission of evidence of subsequent repairs is regulated by a general exclusionary rule developed when most personal injury cases were predicated upon the negligence of the defendant. Such evidence has traditionally been excluded for two reasons-lack of relevance, and a public policy favoring encouragement of repairs. ${ }^{12}$ When recovery for personal injury is predicated upon negligence, at issue is not only the potential for harm of an object which is within the defendant's control, but also the ability of the defendant to foresee that potential for harm before the injury actually occurs. Since the defendant's subsequent actions in repairing the defective condition may show his discovery and realization that the object is capable of causing future harm rather than his negligence in failing to foresee the potential for harm, the evidence of subsequent repairs is frequently not relevant to the issue of negligence. ${ }^{13}$ Such evidence is

12. C. MCCormick, LaW OF Evidence § 252 (1954); 2 J. WIGMore, TREatise ON EviDENCE $§ 283$ (3d ed. 1940). The general exclusionary rule has been held applicable to products liability cases as well as other personal injury cases. See, e.g., Stephan v. Marlin Firearms Co., 353 F.2d 819, 823 (2d Cir. 1965) (subsequent improvement of a rifle not relevant to the question of negligent design); Cox v. General Elec. Co., 302 F.2d 389, 390 (6th Cir. 1962) (alleged negligently designed washing machine); Northwest Airlines v. Glenn L. Martin Co., 224 F.2d 120,130 (6th Cir. 1955) (alleged negligent design and manufacture of airplanes); Foley v. CocaCola Bottling Co., 215 S.IV.2d 314, 317 (Mo. App. 1948) (tacks in soft drink). See also L. Frumer \& M. Friedman, supra note 7, § 12.04 (1964, Supp. 1971).

13. Courts have tended to be more adamant on this point than commentators. Compare Columbia \& Puget Sound R.R.v. Hawthorne, 144 U.S. 202, 207 (1892) ("[T]he taking of such precautions against the future . . has no legitimate tendency to prove that the defendant had been negligent before the accident happened . . . ") and Terre Haute \& 1.R.R. v. Clem, 123 Ind. $15,17,23$ N.E. 965,966 (1890) ("II]t is what occurs prior to the action, not what happens 
relevant to the extent that it establishes that the product was capable of causing injury; 14 however, there is fear that, despite the court's instructions, a jury might construe the defendant's repairmaking as an admission of his negligence or liability. ${ }^{15}$ This potentially prejudicial effect of the evidence conflicts with a strong public interest in encouraging repairs and improvement of injury-causing objects. ${ }^{16}$ Knowledge that post-injury alterations to the injury-causing object could be used to impose liability might discourage a person capable of making repairs from doing so.

\section{Exceptions to the General Rule}

The general exclusionary rule is subject to numerous exceptions which permit evidence of subsequent repairs to be admitted for limited purposes. ${ }^{17}$ Evidence that a party made repairs is admissible to show that he had control over the object and, therefore, a duty to maintain it in a safe condition. ${ }^{18}$ When the injury-causing object has been altered and testimony or photographs of the object in its altered condition are introduced, evidence of the modification is admissible to distinguish the condition of the object at the time of the injury from

afterwards, that determines whether there has or has not been a culpable breach of duty.") with C. MCCormick, supra note $12, \S 252$ ("[I]t would often meet the usual standards of relevancy.") and J. WIGMORE, supra note $12, \S 283$ ("[I]t would suffice for admissibility if merely the inference was a fairly possible one....").

14. It also tends to show that the defect could have been prevented by the manufacturer. See text following note 59 infra.

15. Professor Wigmore believes that it is "plainly false" to assume that the act of improving the condition of an object, after the threat or occurrence of an injury, indicates a belief of negligence on the owner's part; inevitable accidents and contributory negligence are equally plausible reasons. $2 \mathrm{~J}$. WiGMORE, supra, note $12, \S 283$. "To improve the condition of the injury-causing object is therefore to indicate a belief merely that it has been capable of causing such an injury, but indicates nothing more . . . ." Id. See also Columbia \& Puget Sound R.R. v. Hawthorne, 144 U.S. 202, 207 (1892); Terre Haute \& I.R.R. v. Clem, 123 Ind. 15, 17, 23 N.E. 965,966 (1890); Morse v. Minneapolis \& St. L. Ry., 30 Minn. 465, 468, I6 N.W. 358, 359 (1883).

16. This policy was eloquently described in Terre Haute \& I. R.R. v. Clem, 123 Ind. 15, 19, 23 N.E. 965, 966 (1890): "True policy and sound reason require that men should be encouraged to improve or repair, and not be deterred from it by the fear that, if they do so, their acts will be construed into an admission that they had been wrongdoers." See generally C. MCCormick, supra note 12, § 252; 2 J. Wigmore, supra note 12, § 253.

17. For a list of the exceptions and the extensive underlying case law, see C. McCormick, supra note 12, § 252; 2 J. WIGMORE, supra note 12, § 283; Note, Admissibility of Evidence of Subsequent Safety Measures, 37 TEx. L. REv. 478 (1959).

18. See, e.g., Wallner v. Kitchens of Sara Lee, Inc., 419 F.2d 1028, 1032 (7th Cir. 1969), where photographic evidence of repair of machinery by Sara Lee was held properly admissible for the limited purpose of showing that Sara Lee, and not a co-defendant, controlled the conveyor and possessed a duty to make necessary structural changes in the conveyor. 
its present condition. ${ }^{19}$ An additional broad exception to the general exclusionary rule permits evidence of subsequent repairs to demonstrate the feasibility of making the object safer when the defendant has alleged that the condition of the product could not be improved. ${ }^{20}$ This feasibility exception has been extended to admit such evidence not only to rebut the purported reasonableness of industry safety standards, ${ }^{21}$ but also where the plaintiff initially raised the issue of feasibility of improvement and then introduced the otherwise excluded evidence. ${ }^{22}$

\section{Narrowing the General Rule}

Recently, some courts have admitted evidence of subsequent repairs whenever the reasons for exclusion-irrelevancy and encouragement of repairs-are not operative and hence do not justify exclusion of the evidence..$^{23}$ Some judges have limited the exclusionary rule to the benefit of the party who actually made the repair. In Brown $v$. Quick Mix Co. ${ }^{24}$ the plaintiff joined as defendants the manufacturer

19. See, e.g., Eastern Air Lines, Inc. v. American Cyanamid Co., 32। F.2d 683, 690 (5th Cir. 1963), where evidence of the defendant's improvements and preparations for improvements subsequent to an accident was admitted for the limited purpose of showing the condition of defendant's plant at the time of the accident.

20. See, e.g., Hickey v. Kansas City So. Ry., 290 S.W.2d 58, 61 (Mo. 1956), where counsel for defendant stated in his opening remarks that it was impossible to remedy the dangerous railroad crossing where plaintiff was injured. Evidence of a later repair of that crossing was admitted to rebut this contention.

This exception is similar to another exception which permits evidence of subsequent repairs for impeachment-for example, where defendant testifies that the injury-causing object is as safe as possible.

21. See Johnson v. United States, 270 F.2d 488 (9th Cir. 1959), where plaintiff was permitted to show that, after the injury, defendant added an additional barrier to the gate in the fence surrounding its power station even though defendant never contended that such additional precautions were impossible, but only that the pre-accident safety mcasures were those customary to power stations.

22. See, e.g., Brown v. Quick Mix Co., 75 Wash. 2d 833, 839, 454 P.2d 205, 209 (1969): "[T]he evidence is compctent regardless of whether the issue is a part of the plaintiff's case . . . or [whether] the defendant inject[ed] it as a defense." However, Judge Neill, in dissent, criticized the majority for allowing "plaintiff to initially inject evidence of feasibility" and thus enabling the jury to find the defendant negligent "on evidence admitted on an issue which it neither created nor contested." Id. at 842-43, 454 P.2d at 211.

23. The generally recognizcd exceptions are permitted because the specific and limited purposes for which the evidence is admittcd serve an important role in seeking the truth at trial. See, e.g., Hickey v. Kansas City So. Ry., 290 S.W.2d 58 (Mo. 1956), supra note 20. If the assertion that the railroad crossing could not be improved were allowed to stand unrebutted, it would have been extremely prejudicial to the plaintiff's case.

24. 75 Wash. 2d 833, 454 P.2d 205 (1969). 
and retailer of the construction machinery which had caused his injury. The court admitted evidence of a post-accident repair made by the plaintiff's employer, who had not been joined as a defendant. On appeal, the court, in upholding admission of the evidence, noted that since the defendants had not made the repair, the jury would not construe it as an admission of their guilt or their control over the machine. ${ }^{25}$ Arguably, a properly instructed jury would not use such evidence to impute prior knowledge to a defendant who never made repairs and who may never have had any knowledge of the defect-prior or subsequent to the injury. The policy of encouraging repairs is preserved in Quick Mix, since persons will not be discouraged from making repairs if they know evidence of the repair cannot be used against them; therefore, since the evidence is relevant to the proof of defectiveness, it should be admitted for that purpose. This argument is less persuasive, however, when the evidence is admitted against a defendant who did not make the repairs while the repairmaking party is before the court as a co-defendant. In Wallner $v$. Kitchens of Sara Lee, Inc. ${ }^{26}$ the plaintiff joined as co-defendants his employer and the manufacturer of the machine which had caused his injury. Since the employer had made post-injury improvements, the court reasoned that the policy of encouraging repairs which underlies the general rule was inapplicable to the non-repairing manufacturer and that he could not invoke the rule to protect himself from the adverse use of the evidence of subsequent repairs. ${ }^{27}$ The jury could be instructed to consider the evidence as to the manufacturer but not the employer, ${ }^{28}$ and to limit its use of the evidence only to the issues of defectiveness and control, not to the issue of foreseeability. This selective application of the exclusionary rule might promote the public policy of encouraging repairs by insulating the co-defendant who first effects repairs; where the liability for an injury may fall on one of several defendants, a race to repair, in order to avoid the adverse application of the evidence, is conceivable. The danger of the Wallner rationale is the likelihood that the jury will ignore the court's instructions and impute the significance of the evidence to all the defendants. To the extent that the evidence is potentially harmful to all defen-

25. 75 Wash. $2 \mathrm{~d}$ at 840,454 P.2d at 210; accord, Steele v. Wiedemann Mach. Co., 280 F.2d 380, 382 (3d Cir. 1960).

26. 419 F.2d 1028 (7th Cir. 1969).

27. Id. at 1032 .

28. The evidence was admitted against both defendants in Wallner, however, since control was also an issue. Id. See note 18 supra. 
dants, the policy of encouraging repairs is undermined. Furthermore, the Wallner rationale fails to deal adequately with the relevancy issue. If any court is willing to admit evidence of subsequent repairs over objections to its irrelevancy merely because the judge instructs the jury to limit its application to the issues of defectiveness and control, then there is nothing left of the irrelevancy argument. ${ }^{29}$

Courts have also distinguished "repairs" from "technological improvements," admitting evidence of a product's technological improvements not prompted by a specific prior injury. ${ }^{30}$ In Wichman v. Allis Chalmers Mfg. Co., ${ }^{31}$ the defendant-manufacturer developed a protective device for farm machinery already sold and in use. While the devices were being distributed, the plaintiff was injured by a machine not yet equipped with the safety devices. Although the improvement was not a modification in response to the plaintiff's injury, it seems that this is exactly the type of action-either as a repair or technological development-which should be encouraged. Nevertheless, evidence of the change was admitted without adequate consideration of either its relevance or the effect of the admission on the policy of encouraging repairs. ${ }^{32}$ Technically, since the improvement was already made, there was no further need to encourage the manufacturer, and there may be no justification for "rewarding" him by excluding the evidence. Perhaps fear of expanded liability does not significantly discourage technological improvements which may be motivated by a desire to prevent liability from arising in the first place. The preventive nature of this type of improvement is far removed from the understandable reluctance of a potential defendant to repair a product which he knows to have caused an injury for which

29. Cf. Brown v. Quick Mix Co., 75 Wash. 2d 833, 842, 454 P.2d 205, 211 (1969) (dissenting opinion): "It is not realistic to hope that the jury will make the fine distinetions required to differentiate between evidence of the feasibility of making a change to prevent an injury, and negligence itself." An inability of the jury to distinguish between defendants in the use of evidence is just as probable. For additional precautions which the courts must take in admitting evidence in a jury trial, as opposed to a trial before the judge, see Northwest Airlines v. Glenn L. Martin Co., 224 F.2d 120 (6th Cir. 1955). But cf. Boeing Airplane Co. v. Brown, 291 F.2d 310 (9th Cir. 1961).

30. See Stephan v. Marlin Firearms Co., 353 F.2d 819, 823 (2d Cir. 1965): "[T]he exclusionary 'repairs' doctrine did not squarely apply [to an improvement which] represented a technological improvement not prompted by a speeific prior injury." However, the court did state that such evidence could be excluded as irrelevant. Id.

31. 117 F. Supp. 857 (W.D. Mo. 1954), rev'd on other grounds, 220 F.2d 426 (8th Cir.), cert. denied, 350 U.S. 835 (1955).

32. Id. at 860 . 
he may be liable.$^{33}$ Nevertheless, the Wichman court failed to consider the relevance of the evidence, which may not have been probative of the defendant's ability to foresee the potential for harm at the time the machine was manufactured.

\section{A Positive Subsequent Repair Rule}

Limitations on the applicability of the rule excluding evidence of subsequent repairs and improvements have effectively limited the benefit which the defendant derives from the general exclusionary rule. Instead of excluding most evidence of subsequent repairs, courts appear willing, if not eager, to admit such evidence. ${ }^{34}$ With the rule so restricted in its application and subject to many exceptions, it will be a rare plaintiff who cannot find a justification for introducing evidence of subsequent repairs, particularly when several defendants have been joined in the action. The rule no longer appears to be one of general exclusion; rather, the rule for evidence of subsequent repairs may now be a positive rule of admissibility subject only to the exception that evidence of subsequent repairs is admissible unless it is used against the party who made the repair as an admission of his negligence..$^{35}$

\section{Evidence of Subsequent Repairs in STRICt Liability and IMPLIED WARRANTY CASES}

Though there is a tendency toward more general admissibility of evidence of subsequent repairs in negligence cases, there has been little consideration of the application of the exclusionary rule to products liability cases predicated upon strict liability in tort and implied warranty theories. The inherent proof and policy differences between

33. The maker of technological improvements probably will be more influenced by the possibility of economic gain derived from marketing a "technologically improved" product. See also text following note 46 infra.

34. Once the court has admittcd evidence of subsequent repairs, the plaintiff may be free to introduce evidence of repairs of defects which have no causal connection to the injury. $C f$. Boeing Airplane Co. v. Brown, 291 F.2d 310, 315-16 (9th Cir. 1961), where, although defendant was willing to admit changes had occurred, plaintiff was allowed to introduce evidence of specific changes. When the evidence of changes went beyond those defects which were shown to have a causal connection to the injury, the court held that as long as ultimate responsibility was placed upon a defect, inquiry into defects beyond the one actually causing the injury was relevant.

35. See Wallncr v. Kitchens of Sara Lee, Inc., 4 I9 F.2d 1028, 1032 (7th Cir. 1969), where the court stated: "Evidence of post-accident repairs or changes is properly introduced for any purpose except to demonstrate the negligence of a defendant." 
negligence and these new theories may justify disregarding the rule altogether.

\section{Relevancy}

In products liability cases predicated upon strict liability in tort and implied warranty, at issue is not foreseeability but rather the product's defective condition and the defendant's control over the product. Post-accident repair or improvements have been recognized as relevant to the issues of defectiveness and control even in negligence-based cases. ${ }^{36}$ Admitting evidence of subsequent repairs to show defectiveness in the strict liability case is similar to the established exception which permits admission of such evidence to demonstrate the feasibility of improvement in the negligence setting. The purpose is the same-to demonstrate the defendant's ability to make a safer product. Furthermore, since negligence is not at issue, there is less likelihood that the evidence will be misdirected to establish defendant's prior misconduct. ${ }^{37}$

Evidence of subsequent repairs is also valuable as an aid to the jury in determining the Iegal defectiveness of the injury-causing product. A product is considered to be legally defective if it is "unreasonably dangerous" or "unmerchantable." 38 By comparing the repaired or improved product with the original injury-causing product, the jury may draw inferences as to the feasible degree of safety in a product. The trier of fact is then better able to determine the degree of safety needed to conform to the standard of reasonable safety or merchantability. ${ }^{39}$ This use of evidence of subsequent repairs was

36. See note 15 supra. See also Steele v. Wiedemann Mach. Co., 280 F.2d 380 (3d Cir. 1960). The defendant-manufacturer introduced evidence that the plaintiff's employer ordered a replacement part subsequent to the plaintiff's injury, contending that the evidence established that the original part was worn or missing and that this worn or missing part, not a defect, was responsible for the plaintiff's injury. The plaintiff sought to exclude the evidence by offering other equally plausible explanations for the ordering of the replacement part. Recognizing that the employer's actions could be explained by various hypotheses, not all of which tended to prove the defectiveness of the original part, the court held that the proponent of evidence need only show the probability of the desired conclusion to shift the burden of establishing other probable explanations to his opponent. Id. at 382-83.

37. See note 29 supra and accompanying text.

38. See note 7 supra and accompanying text.

39. See Johnson v. United States, 270 F.2d 488, 491-92 (9th Cir. 1959), cert. denied, 362 U.S. $924(1960)$. The issue was the standard of reasonable care for a fence surrounding a high voltage power plant. Defendant offered expert testimony on the established industry practice. Plaintiff offered evidence of subsequent repairs to rebut the contention that the customary practice constituted reasonable care by showing the practicality of additional safeguards. $C f$. 
recognized in Rosin v. International Harvester Co. ${ }^{40}$ where the plaintiffs expert witness compared an original injury-causing part to an improved replacement part, thus aiding the jury in its determination of whether. the original was adequate for its intended purpose or whether the quality of the improved part was the appropriate standard for a reasonably safe design. ${ }^{41}$ In a products liability case, therefore, where the issue is the defectiveness of the product rather than the negligence of a defendant, evidence of subsequent repairs is relevant to the proof of a reasonably attainable safety standard to which the quality of the injury-causing product can be compared.

Evidence of subsequent repairs is also relevant to the issue of the defendant's control over the defective. product. ${ }^{42}$ When the product has passed through several distributors or has been in the plaintiffs control for a substantial period of time, the plaintiff must establish that the defect was in existence while the product was under the defendant's control and overcome the possibility of intervening causes. Since it is reasonable to suppose that a defendant who is now capable of repairing a defect must have previously had that defect under his control, the evidence of subsequent repair is probative of the defendant's control over the defect. Evidence of subsequent repairs is already admissible as an exception to the general rule to prove control when disputed in negligence cases. In the strict liability setting the recognized exception may become the rule.

\section{Policy of Encouraging Repairs}

Although there can be no objection to the relevance of evidence of subsequent repairs in a strict liability case, the public policy favoring encouragement of repairs still exists and merits protection. It can be argued that the defendant will be deterred from making needed repairs by the realization that he is providing evidence for a potential plaintiff under any theory of liability. However, the balance of policy considerations has not remained static under the new theories of

Gasteiger v. Gillenwater, 57 Tenn. App. 206, 213-14, 417 S.W.2d 568, 572 (1966). Experts testified to a minimum industry standard for the construction of a set of steps. The jury was allowed to use evidence of subsequent repairs to steps which had collapsed to determine if the repairs were required to bring the steps within the minimum standard as established by the expert testimony.

40. 262 Minn. 445,115 N.W.2d 50 (1962).

41. 262 Minn. at 453,115 N.W.2d at 55 .

42. See notes 8-11 supra and accompanying text. 
products liability. Strict liability in tort and implied warranty without privity are reflections of a policy decision-one who markets defective products should be responsible for injuries caused by those products. ${ }^{43}$ Exclusion of relevant evidence which aids an injured plaintiff to recover against the distributor ${ }^{44}$ of a defective product contradicts that policy decision.

One reason for applying strict liability is to encourage the distributor of mass-produced goods to market safer products. ${ }^{45}$ If the plaintiff has a lighter burden of proof, distributors will take greater precautions to avoid the increased incidence of liability. It would be inconsistent to encourage greater care by threatening increased liability and, at the same time, to exclude relevant and essential evidence from the litigation.

The assumption that the admission of evidence of subsequent repairs discourages defendants from making required repairs may be erroneous. Manufacturers and distributors of mass-produced products may not be so callous to the safety of the consumer as the general exclusionary rule presumes. ${ }^{46}$ Furthermore, to the extent that admission of such evidence results in recovery by injured plaintiffs, it can be argued that evidence of subsequent repairs encourages future remedial action. A distributor of mass-produced goods may have thousands of goods on the market. If his products are defective, the

43. "[S]ociety's interest [demands an elimination of the requirement of privity so that] the burden of losses consequent upon use of defective articles is borne by those who are in a position to either control the danger or make an equitable distribution of the losses when they do occur." Henningsen v. Bloomfield Motors, Inc., 32 N.J. 358, 379, 161 A.2d 69, 81 (1960); accord. Greenman v. Yuba Power Prods., 59 Cal. 2d 57, 63, 377 P.2d 897, 901,27 Cal. Rptr. 697, 701 (1967). See also Escola v. Coca-Cola Bottling Co., 24 Cal. 2d 453, 462, 150 P.2d 436, 440-41 (1944) (Traynor, J., concurring). But cf. Prosser, supra note 5, at 799-800, suggesting that the courts rely mainly on the manufacturer's ability to prevent defects, and that "[t]he 'risk distributing' theory - the supplier should be beld liable because he is in a position to insure against liability and add the cost to the price of his product-has been an almost universal favorite with the professors; but it has received little mention in the cases, and still appears to play only the part of a makeweight argument."

44. The products liability plaintiff can recover from anyone in the distribution chain, from manufacturer to retailer. See note 55 infra and accompanying text. The term "distributors" hereinafter will be used generically to denote all those in the distribution chain whom the plaintiff may sue.

45. See Carmichael 531-32. But see Prosser, The Assault Upon the Citadel (Strict Liability to the Consumer), 69 Y ALE L.J. 1099, III9 (1960).

46. See Kennelly, Litigation of an Aircrash Case Against Manufacturer and Airline Which Resulted in Verdict for Two Million Dollars for Single Death, 1965 TRIAL LAWYER'S GUIDE 153, 203-04, describing the rule against evidence of subsequent repairs as "horse and buggy law, totally inconsistent with the conduct of manufaeturing industries of the world today." See also Prosser, supra note 45, at 1119. 
distributor would probably face greater total liability by allowing such defective products to remain on the market or by continuing to put more defective products on the market than he would by being adjudged liable in one particular case where evidence of subsequent repairs was introduced. Also, concern on the part of the distributors for consumer protection is promoted by consumer organizations, federal agencies, and mass media exposure of product defects. ${ }^{47}$ To some extent, the economic self-interest of product distributors requires that they repair and improve defective products to avoid adverse publicity which might result from future litigation. Since a prior jury finding of product defectiveness is admissible in a subsequent suit when the product causing the second injury is substantially similar to the first, ${ }^{48}$ distributors of defective products are under pressure to repair or alter their products to insulate themselves from a finding of defectiveness which may be used against them in subsequent litigation.

In conclusion, excluding evidence of subsequent repairs to encour-

47. Cf. Carmichael 531 .

For example, consumer protection groups, a government agency and mass media joined forces to expose a defect in Chevrolet automobiles and forced General Motors to recall millions of cars to install safety devices. After months of investigation by the National Highway Traffic Safety Administration and auto safety critic Ralph Nader and his associates, GM responded to "rising governmental pressure" and "voluntarily announced" the recall, blaming " "publicity" given the engine mount issue." The recall was made only after "a number of accidents and lawsuits [had been] reported." Wall St. J., Dec. 6, 1971, at 4, col. 2.

48. See Prashkcr v. Beech Aircraft Corp., 258 F.2d 602, 608 (3d Cir. 1958); Berry v. Fruehauf Trailer Co., 371 Mich. 428, 430, 124 N.W.2d 290, 291 (1963). Res judicata or collateral estoppel would not be applicable in such a case. Hypothesized is a situation where, for a period of timc after a product defect caused injury, the distributor could have, but did not, make repairs, and a similar product caused a sccond injury. Res judicata application-for the benefit of a plaintiff not a party to earlier litigation in which the issues of defectiveness or control were found against the same dcfendant-requires at least that: the issues be identical; the defendant have full and fair opportunity to litigate the issues, including a non-hostilc forum and reasonable opportunity and motivation to exhaust all appeals; and the defendant have full knowledge of other plaintiffs waiting in the wings to use the fact findings collaterally. Res judicata for thc benefit of new plaintiffs is best appliable to mass accident cases where many plaintiffs, injured by a single product defect, bring a series of suits against the same defendant. Res judicata would not bc applicable in the situation hypothesized because the defendant may not be aware of other potential plaintiffs since the occurrence being litigated did not produce a mass accident, and there might not be the same motivation for exhaustive litigation or appeal. See Currie, Civil Procedure: The Tempest Brews, 53 CALIF. L. Rev. 25, $27-37$ (1965). Compare Zdanok v. Glidden Co., 327 F.2d 944 (2d Cir. 1964) and United Statcs v. United Air Lines, Inc., 216 F. Supp. 709 (E.D. Wash., D. Nev. 1962), modified on other grounds sub nom., United Air Lines, Inc. v. Wicner, 335 F.2d 379 (9th Cir. 1964) with Berner v. British Commonwealth Pac. Airlines, Ltd., 346 F.2d 532 (2d Cir. 1965), cert. denied, 382 U.S. 983 (1966). In mass accident litigation where res judicata is applicable, the distributor of a defective product has no opportunity to make repairs subsequent to his discovery of the defect. 
age future remedial action may preclude recovery under theories of products liability which are themselves designed to ensure safety in marketed products. Relevant evidence should not be excluded from a products liability case by an obsolete evidentiary rule when modern legal theories, accompanied by economic and political pressures, will achieve the desired policy goals.

\section{Problems With the Admission of Evidence of Subsequent REPAIRS}

If the necessity of admitting evidence of subsequent repairs is conceded, the courts must nevertheless contend with different problems caused by admission of such evidence. In addition to the persistent problem of possible jury misuse of the evidence, a new problem arises-how does the evidence of subsequent repairs apply to technologically new products or products for which there has been a technological breakthrough in design?

\section{Jury Misuse of the Evidence}

The jury may infer an admission of liability from the defendant's repair-making. ${ }^{49}$ Juries should not be permitted to find the defendant liable on such evidence alone in disregard of such other essential elements of the plaintiff's case as proximate cause, legal defectiveness of the product, and control by the defendant. The court must ensure that the plaintiff has introduced independent evidence for all material elements of his case, that a factual dispute exists for jury resolution, and that the jury is properly instructed to restrict its use of the evidence of subsequent repairs to the issues of defectiveness and control.

Although subsequent remedial action is relevant to the issue of defectiveness, it is neither an admission nor conclusive proof that the product was in fact defective. A proper use of evidence of subsequent repairs is to aid the jury in establishing a standard of reasonable safety or merchantability to which it can compare the quality of the injury-causing product. ${ }^{50}$ It is difficult, however, to distinguish between defectiveness in the sense that the product might have been improved, and legal defectiveness because the product was

49. Courts have expressed a similar concern in cases predicated upon negligence. See note 15 supra and accompanying text.

50. See notes $39-41$ supra and accompanying text. 
unreasonably dangerous or unmerchantable. ${ }^{51}$ Since the jury may find the product legally defective only if the injury-causing product failed to conform to a standard of reasonable safety or merchantability established by competent evidence, the need remains for careful instructions as to the proper use of evidence of subsequent repairs.

Products liability litigation can be predicated upon multiple theories; a single products liability complaint often alleges the defendant's negligence, his strict liability in tort, and his violation of an implied warranty. ${ }^{52}$ Since evidence of subsequent repairs is not relevant to the issue of the defendant's ability to foresee the consequences of his conduct, the court may avoid the possibility of jury misuse of the evidence for the issue of defendant's negligence by totally excluding evidence of subsequent repairs from all cases in which negligence is pleaded. Thus, the plaintiff may be forced to choose between the value of the introduction of such evidence for his strict liability and implied warranty claims and the value of retaining an allegation of the defendant's negligence. ${ }^{53}$ Alternatively, the court may view this as a problem inherent in the admission of any evidence and protect against the additional possible misuse of evidence of subsequent repairs by employing the usual techniques of close supervision of the

51. Prosser, supra note 5, at 809-10. See note 7 supra.

The following test for "legally defective" has been proposed:

(l) The product carries a significant physical risk to a definable class of consumer and the risk is ascertainable at least by the time of trial.

(2) The risk is one that the typical member of the class does not anticipate and guard against.

(3) The risk threatens established consumer expectations with respect to a contemplated use and manner of use of the product and a contemplated minimum level of performance.

(4) The seller has reason to know of the contemplated use and, possibly where injurious side effccts are involved, has reasonable access to knowledge of the particular risk involved.

(5) The seller knowingly participates in creating the contemplated use, or in otherwise generating the relevant consumer expectations, in the way attributed to him by the consumer. Dickerson, supra note 7, at 331.

See generally Prosser, supra note 5, at 807-14.

52. See, e.g., Brown v. Quick Mix Co., 75 Wash. 2d 833, 545 P.2d 205 (1969), where plaintiff based his claim upon the manufacturer's negligence and implied warranty of fitness, and the court added that he also could have pleaded strict liability in tort as expressed in RestatEMENT \& 402A.

The Restatement has expressly stated that strict liabiliy in tort is not to be an exclusive remedy for personal injury. Id. comment $a$.

53. A possible value of proving negligence is that establishing the blameworthiness of the defendant's prior misconduct may play upon the jury's sympathies, resulting in higher general damages or even punitive damages. 
trial and proper instructions limiting the jury's use of evidence to the issues of strict liability and implied warranty. Such limiting instructions, however, are the type available in any negligence case and have generally not been employed by the courts, which have instead chosen to exclude the evidence as irrelevant to the issue of negligence..$^{54}$ Since the irrelevancy of subsequent repairs generally has been held sufficient to bar the evidence from negligence cases, the former approach of denying the use of such evidence where negligence is pleaded may be the more logically consistent, albeit the harsher, solution.

The products liability plaintiff will probably join as defendants all those in the distribution chain of the product-from manufacturer to retailer ${ }^{55}$ The retailer may cross-claim ${ }^{56}$ or bring a third-party ac$\operatorname{tion}^{57}$ against the wholesaler for indemnity; the wholesaler may in turn cross-claim against the manufacturer, who becomes the primary defendant or indemnitor. ${ }^{58}$ When the jury must decide the indemnity claims as well as the plaintiff's claim, the issue of control becomes more significant since the jury must determine under whose control the product first became defective. The creation of the defect cannot be inferred solely from a defendant's ability later to correct the defect; the retailer or even the owner of the defectively manufactured product may make the repairs..$^{59}$ Similarly, subsequent distributors or users of a safely manufactured product may assemble or modify it in such a way as to render it dangerous. The manufacturer then may make a "subsequent repair" which renders the product immune from such dangers. With the denials of negligence which may occur in multi-party litigation, the court must carefully instruct the jury to trace the defect back to the party responsible for the origin of the

54. See notes 12-13 supra and accompanying text.

55. ResTATEMENT $\$ 402 \mathrm{~A}$, comment $f$; Prosser, supra note 5 , at $814-17$. The purpose of joining all defendants of the distribution chain is to avoid possible defenses which may be available to one, but not all, of the defendants. For example, a manufacturer may claim alteration or change of the product by the wholesaler or retailer, thereby escaping liability. See Carmichael 556-57.

56. FED. R. Civ. P. 13(g).

57. Id. 14(a).

58. See Stewart v. Budget Rent-A-Car Corp., 52 Hawaii 71, 78-79, 470 P.2d 240, 244-45 (1970) (leasing agency's cross-claim against distributor and manufacturer allowed); Farr v. Armstrong Rubber Co., 288 Minn. 83, 95-97, 179 N.W.2d 64, 72-73 (1970) (a retailer liable solely because of its passive role as the seller of a product furnished to it by the manufacturer is entitled to indemnity). See Carmichael 556-57.

59. See, e.g., Wallner v. Kitchens of Sara Lee, Inc., 419 F.2d 1028 (7th Cir. 1969); Brown v. Quick Mix Co., 75 Wash. 2d 833, 454 P.2d 205 (1969). 
defect, even though others may have demonstrated control by later modifying the product. ${ }^{60}$

\section{New Products}

When new products are developed, changes can be expected as defects which were not ascertainable during development and experimentation are discovered and technological improvements are initiated as a result of the knowledge generated from actual use. Evidence of subsequent repairs and improvements may be beneficial in determining a standard of reasonable safety or merchantibility, but the significance of such evidence should not be overemphasized. ${ }^{61}$ There may be flaws in new products, but whether these flaws are "legal defects" is a more difficult question. Newly developed products may be unique. The standard of merchantability implies the existence of similar goods with which to compare the new product. ${ }^{62}$ Similarly, the standard of reasonable safety requires only that dangers in a product not be "unreasonable." 63 Reasonableness is a relative concept, and greater dangers may be tolerated in new products before holding the distributor liable. The standard of reasonable safety may become more stringent as technological improvements are made, but the standard prevailing at the time the injury-causing product was distributed should be applied. ${ }^{64}$ The same analysis is applicable to those technological breakthroughs in design or manufacturing methods of established products. Measured by the state of the technological art then

60. Consider, for example, Wallner v. Kitchens of Sara Lee, Inc., 419 F.2d 1028 (7th Cir. 1969), where plaintiff, injured by a machine, joined as defendants the owner of the machine and the manufacturer-designer. The owner of the maehine who had made a post-injury repair filed a cross-claim against the manufacturer-designer and a third-party action against the installer-maintainer of the machine asking indemnity from each if he was found liable to plaintiff.

61. Cf. Stephan v. Marlin Firearms Co., 353 F.2d 819 (2d Cir. 1965). The court said that, although evidence of technological improvements was not barred by the rule excluding evidence of subsequent repairs, technological improvements were "not relevant, according to principles of 'American ingenuity of design manufacture,' to the issue of prior negligent design." Id. at 823.

62. UNIFORM COMMERCIAL CODE $§ 2-314(2)(c)$.

63. REstatement $\S 402 A(1)$.

64. See Stephan v. Marlin Firearms Co., 353 F.2d 819, 823 (2d Cir. 1965) ("[the manufacturer] is an insurer against foreseeable risk-but not against unknowable risks"); Lartigue $v$. R. J. Reynolds Tobacco Co., 317 F.2d 19, 35-37 (5th Cir. 1963); Oakes v. Geigy Agric. Chems., 272 Cal. App. 2d 645, 77 Cal. Rptr. 709 (Dist. Ct. App. 1969); Restatement $\S 402$ A, comment $k$; Dickerson, supra note 7, at 327-28. See generally Prosser, supra note 45, at 1143-45. But see Pritchard v. Liggett \& Myers Tobacco Co., 295 F.2d 292 (3d Cir. 1961); Green v. American Tobacco Co., 154 So. 2d 169, 170-74 (Fla. 1963). 
existing, the pre-breakthrough product may be reasonably safe, even though subsequently acquired technological skills would require a higher degree of safety in later models. Evidence of subsequent repairs and improvements may be relevant to the reasonableness of the previous standard, but should not dictate a standard not previously attainable and therefore not applicable.

Nevertheless, the standard of reasonable safety may depend not only upon the stage of the product development, but also upon the nature of the product. Products which are marketed for use or consumption by individuals who must rely upon the product without a thorough inspection for possible defects, and which by their nature are the type of product consumers would reasonably expect to be safe, should conform to a high standard of safety before they are put on the market. New food products, automobiles of innovative design, and most mass-produced consumer products should be sold only after the manufacturer has taken every possible precaution against defects. Individual consumers injured by such products should be permitted to introduce evidence of subsequent repairs or improvements to suggest to the jury a high standard of safety. On the other hand, products which by their nature are inherently dangerous but which, if technology should change, may become reasonably safe, arguably need only conform to the pre-technological breakthrough standard so long as consumers know of the inherent danger and accept the risk. ${ }^{65}$ In such a case, evidence of subsequent remedial action should not be used to establish an artificially high standard of reasonable safety.

\section{CONCLUSION}

Evidence of subsequent repairs and improvements is relevant to the products liability plaintiff's proof of product defectiveness and the defendant's control. Exclusion of such evidence to encourage repairmaking diminishes the impact of new legal theories and may be unnecessary in view of consumer and government groups which promote product safety. Evidence of subsequent repairs remains subject to jury misuse, but courts have confronted similar problems with other evidence and have developed techniques to eliminate or minimize that possibility. Evidence of subsequent repairs may be introduced in cases where the risk of injury is not appropriately shifted from plaintiff to defendant; that problem requires a consciousness of

65. See note 64 supra and accompanying text. 
the ends for which the new products liability theories were developed and the exclusion of evidence which fails to serve those ends. A policy decision has been made by courts and legislatures to eliminate the cost of injury for individual consumer-plaintiffs who are powerless to protect themselves against injury from defective products. Evidence of subsequent repairs and improvements should be admissible to implement that policy decision. 
THE BLIREAU OF NATIONAL AFFAIRS, INC. (BNA) cordially ínuites you to try

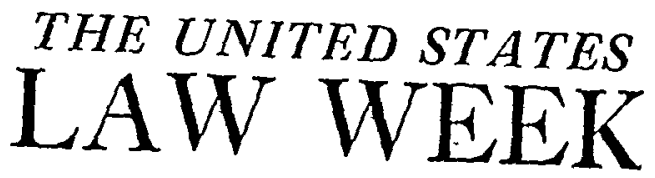

for three months at half the regular rate!

As an attorney, you know the value of facts. That's why the following facts, regarding THE UNITED STATES LAW WEEK, should be particularly meaningful to you:

The primary function of LAW WEEK is to safeguard you against missing a single development of legal importance ... yet to save your time by greatly reducing your reading load!

a To do this, LAW WEEK's expert staff of lawyer-editors sifts thousands of opinions and rulings week by week, year after year, for the precedentsetting few that make new law. These significant cases are then digested under quick-reference topic headingssuch as Antitrust, Taxation, Insurance, Public Contracts, Labor, Transportation, Trade Regulation, Criminal Law, Public Utilities, Railroads-in the appropriate section of LAW WEEK: (1) New Court Decisions, (2) Federal Agency Rulings, or (3) Supreme Court Opinions.

To further save your time, the opinions and rulings appearing in all sections of LAW WEEK are highlighted in a special Summary and Analysis, a five-minute review in which these legal developments are tersely evaluated for their effect on current law.

A key feature of LAW WEEK is its high-speed reporting of Opinions of the United States Supreme Court-in full text, accompanied by crisp and accurate summary digests. Mailed the same day they are handed down, these exact photographic reproductions of the Court's Opinions eliminate all possibility of error.

- LAW WEEK also supplies the full texts of all federal statutes of general interest, immediately after signing by the President.

a For ease of reference, LAW WEEK is fully indexed by topic and by case title-both for general law and for Supreme Court actions.

If you concur in the opinion that LAW WEEK might be helpful to you, the special infroductory rate (three months at half the regular rate) affords you an ideal opportunity to get ac. quainted with this valuable information service.

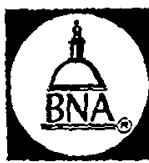

For further information, please contact:

THE BUREAU OF NATIONAL AFFAIRS, INC. 123125 th St. N.W., Washington, D.C. 20037 